\title{
Vibration syndrome in Forestry Commission chain saw operators
}

\author{
W. TAYLOR, J. PEARSON, R. L. KELL, and G. D. KEIGHLEY \\ The Department of Social and Occupational Medicine, University of Dundee, and the \\ Forestry Commission of Great Britain
}

Taylor, W., Pearson, J., Kell, R. L., and Keighley, G. D. (1971). Brit. J. industr. Med., 28, 8389. Vibration syndrome in Forestry Commission chain saw operators. A preliminary investigation has been made into the prevalence of the vibration syndrome in the employees of the Forestry Commission (Britain). A questionnaire covered 20 randomly selected employees for each of $\mathbf{4 0}$ forests chosen at random, giving a total sample of 800 out of 9600 employees. Of the 756 employees still with the Forestry Commission, 732 responded $(97 \%)$. The analyses were confined to the 711 male employees, of whom 142 were chain saw operators. In this number, the prevalence of the vibration syndrome was $44 \%$ whereas in men who did not handle the chain saw the prevalence was significantly lower at $18 \%(0.005$ level of significance $)$. A regional difference was found. South England showed the highest rate at $69 \%$ compared with North England at $31 \%$ and Scotland at 33\%. An increase in prevalence with years of chain saw usage was found, starting at around two years with a marked increase $(73 \%$ at over eight years. In part, this effect explains the regional differences. Men with the syndrome were significantly more affected by chilling at work, during rest periods, and while sheltering from bad weather, with blanching of the fingers $(89 \%)$ most affected by the weather, followed by sensory loss $(84 \%)$.

During the survey vibration levels were measured on 18 chain saws. The major vibration component from each saw fell within the $125 \mathrm{~Hz}$ octave band and the vibration levels considerably exceeded the criterion of Axelsson (1968). In 16 of the saws the amplitudes were greater on the lower (trigger) handle.

Pneumatic vibrating tools were first used in French mines in 1839. In 1911, Loriga in Rome described vascular spasm of the blood vessels in the hands (Raynaud's phenomenon) attributable to the use of pneumatic tools. Hamilton (1918) studied miners using drills in the limestone quarries of Indiana and described 'spastic anaemia' of the hands. More than 20 years later, Raynaud's phenomenon in rotating tools, giving rise to vascular spasm, was recognized in America (Dart, 1946; Peters, 1946) and in Britain (Agate and Druett, 1947; Agate, 1949). However, 10 years later Pecora, Udel, and Christman (1960), in a survey in America, indicated that Raynaud's phenomenon of occupational origin had by the year 1960 become 'an uncommon occupational disease approaching extinction'.

\section{Prescription in Great Britain}

During the period 1950 to 1954 the Industrial Injuries Advisory Council of the Ministry of Pensions and National Insurance in Britain made a detailed examination of Raynaud's phenomenon with a view to prescribing this condition as an industrial disease for the purpose of benefit under the Industrial Injuries Act, 1946. The Advisory Council in December 1954 advised against prescription.

In April 1965, the Advisory Council was again asked to investigate the question of prescription and whether any new evidence was forthcoming on (a) the prevalence and severity of Raynaud's phenomenon in employees using vibrating tools, (b) the establishment of the vibration characteristics 
giving rise to Raynaud's phenomenon, and (c) means of distinguishing occupational cases of Raynaud's phenomenon from non-occupational. In their investigation, the definition has been broadened to include diseases of bone, joints, muscles, blood vessels or nerves of the hand, arm or shoulder (including Raynaud's phenomenon) caused by vibrating machines. This complex has been designated the 'vibration syndrome'. In July 1970, the Industrial Injuries Advisory Council issued an Interim Report.

The results of this survey were submitted to their Industrial Diseases Sub-committee in 1969. The Sub-committee concluded that further research was necessary into the condition of vibration-induced white finger (Vibration Syndrome, 1970).

\section{Role of power chain saws}

Throughout the 1960s in Britain, as in other countries, evidence was accumulating that a new vibrating tool - the power-driven chain saw - was giving rise to subjective signs and symptoms of Raynaud's phenomenon. The chain saw was first introduced by timber fellers in Germany before the second world war and in Sweden in ever increasing numbers in the early 1950s. With the increasing mechanization of forest work in all timber-growing countries, the chain saw has undergone steady technical development and is now widely used for felling, cross-cutting, and limbing (or snedding). By 1965, 40000 power saws were sold in Sweden alone and the utilization time had increased from $1 \frac{1}{2}$ to 2 hours per day in 1950 to 4 to 6 hours in 1967-8 (Axelsson, 1968). The signs and symptoms arising from the use of power saws in forestry operations and reported from Japan, Sweden, and Australia (Miura, Kimura, Tominaga, and Kimotsuki, 1966; Axelsson, 1968; Kylin, Gerhardsson, Hansson, Litstrom, Ligenberg, Swensson, and Astrand, 1968; Barnes, Longley, Smith, and Allen, 1969) were (a) blanching of the fingers, $(b)$ sensory loss in fingers and palms of the hands, $(c)$ coarse tremor of the hands, $(d)$ pain on returning circulation, $(e)$ cyanosis of the fingers, $(f)$ osteoporosis of the phalanges, $(g)$ cystic changes in the carpal bones, and $(h)$ wrist, elbow, and shoulder joint pain. The 'white', cold, numb fingers occur at first only when triggered off by the stimulus of the saw vibration, i.e., at work. Once established, however, by repeated trauma, attacks may be readily induced by cold, initially at work, but later, after 1 to 2 years' saw usage, by hobbies such as sea bathing, fishing, and gardening. This response to lowered environmental temperature is widely reported and the evidence suggests a distinct geographical distribution with a higher prevalence of 'white finger' in the colder, northern forestry areas of Russia, Canada, Finland, and Sweden.
In 1968, the Forestry Commission of Britain and the Department of Social and Occupational Medicine, University of Dundee began an investigation of this problem. The first part of this study consists of (a) measurement of vibration in chain saws in use in two forests in Scotland, and (b) estimation of the prevalence of the syndrome in Great Britain, as indicated by the subjective symptoms of blanching, numbness, and pain in the fingers. The aim of the second part of this study will be to develop objective tests to measure disability or handicap arising as a result of chain saw usage.

\section{Vibration characteristics of chain saws}

Two investigations were made, the first on seven chain saws in use in two forests in Scotland, by the Department of Social and Occupational Medicine (Dundee), and the second on 11 new chain saws, four with anti-vibration handles, by the National Institute of Agricultural Engineering (NIAE). The results have been combined in Table 1.

Dundee method The vibration intensity and frequency characteristics of power saws, chosen at random, were recorded in the field and subsequently analysed in the laboratory. All measurements were made cross-cutting a horizontal $\log , 9$ in to $1 \mathrm{ft}(23$ to $30 \mathrm{~cm})$ in diameter. A calibrated Bruel and Kjaer accelerometer, type 4313, was attached to each saw handle in turn and in each of three mutually perpendicular directions. The accelerometer was mounted rigidly on the saw handle and connected via a B. \& K. ZR0020 integrator and a B. \& K. 2203 sound level meter to a Nagra IIIb tape recorder. Acoustic calibration signals from a B. \& K. pistonphone were used to define the recording level.

In the laboratory, loops from the tape recordings were analysed by a B. \& K. audiofrequency spectrometer and pen recorder. The true vibration level was obtained from the calibration signal.

Analysis records were made in octave bands centred at $31.5 \mathrm{~Hz}$ to $8 \mathrm{kHz}$ for each of the three directions. The vibration amplitudes were summed, as vectors for each octave band, and the total vibration level for a saw handle was determined from the addition of the vibration levels in all the octave bands. The vector values are given in microns (micrometres) as a measure of displacement from the at-rest position.

NIAE method The NIAE method is similar to that of Dundee. The output from the accelerometer (B. \& K. type 4329) mounted in three positions on each handle was connected through a cathode follower amplifier (B. \& K. type $1606 / 2107$ ) to an ultraviolet light galvanometer recorder and FM tape recorder (Thermionics T400). The frequency response of this instrumentation is flat over the range 5 to $500 \mathrm{~Hz}$ and calibration signals were introduced by mounting the accelerometer on $\mathrm{a} \pm 10 \mathrm{~g}$ vibration generator. Measurements were made while cross-cutting, felling, and snedding, but only the cross-cutting results are given for comparison with the Dundee measurements.

Results of vibration analysis A summary of the overall vibration levels is given in Table 1, for the upper handle, 
TABLE 1

Chain Saw Vibration: Summary of Measurements

\begin{tabular}{|c|c|c|c|c|c|c|c|c|c|c|}
\hline \multirow{3}{*}{$\begin{array}{c}\text { Saw maker } \\
\text { (letter) and } \\
\text { type (no.) }\end{array}$} & \multirow{2}{*}{\multicolumn{2}{|c|}{ Measured by }} & \multicolumn{4}{|c|}{ Upper handle } & \multicolumn{4}{|c|}{ Lower handle (trigger) } \\
\hline & & & \multicolumn{2}{|c|}{$\begin{array}{l}\text { Displacement } \\
\left(\text { (microns }^{2}\right)\end{array}$} & \multicolumn{2}{|c|}{$\begin{array}{l}\text { Frequency of major } \\
\text { component }\end{array}$} & \multicolumn{2}{|c|}{$\begin{array}{l}\text { Displacement } \\
\left(\text { microns }^{2}\right)\end{array}$} & \multicolumn{2}{|c|}{$\begin{array}{l}\text { Frequency of major } \\
\text { component }\end{array}$} \\
\hline & Used saws & New saws & Range & Peak & $\begin{array}{c}\text { Octave band } \\
\text { centre } \\
\text { frequency }(\mathrm{Hz})\end{array}$ & $\mathrm{Hz}$ & Range & Peak & $\begin{array}{c}\text { Octave band } \\
\text { centre } \\
\text { frequency }(\mathrm{Hz})\end{array}$ & $\mathrm{Hz}$ \\
\hline $\begin{array}{l}\text { A1 } \\
\text { A1 } \\
\text { A1 } \\
\text { A2 } \\
\text { A3 } \\
\text { B1 } \\
\text { B1 } \\
\text { C1 } \\
\text { C2 } \\
\text { C2 } \\
\text { C2 } \\
\text { C3 } \\
\text { D1 } \\
\text { D2 } \\
\text { E1 } \\
\text { F1 } \\
\text { F2 } \\
\text { G1 }\end{array}$ & $\begin{array}{l}\begin{array}{l}\text { Dundee } \\
\text { Dundee }\end{array} \\
\text { Dundee } \\
\text { Dundee } \\
\text { Dundee } \\
\text { Dundee } \\
\text { Dundee }\end{array}$ & $\begin{array}{l}\text { NIAE } \\
\text { NIAE } \\
\text { NIAE } \\
\text { NIAE } \\
\text { NIAE } \\
\text { NIAE } \\
\text { NIAE } \\
\text { NIAE } \\
\text { NIAE } \\
\text { NIAE } \\
\text { NIAE }\end{array}$ & $\begin{array}{r}270-280 \\
250-370 \\
\\
250-325 \\
\\
325-540 \\
370-500 \\
300-360 \\
320-440\end{array}$ & $\begin{array}{c}300 \\
\\
450 \\
300^{1} \\
425 \\
580 \\
590 \\
155^{1} \\
\\
115^{1} \\
\\
530 \\
340 \\
90^{1}\end{array}$ & $\begin{array}{l}125 \\
125 \\
\\
125 \\
500\end{array}$ & $\begin{array}{r}125 \\
\\
140 \\
130 \\
140 \\
\\
140 \\
145 \\
40\end{array}$ & $\begin{array}{l}400-450 \\
820-855 \\
440-640 \\
610-820\end{array}$ & $\begin{array}{l}700 \\
\\
500 \\
560^{1} \\
500 \\
\\
660 \\
710 \\
170^{1}\end{array}$ & $\begin{array}{l}125 \\
125 \\
\\
125 \\
125\end{array}$ & $\begin{array}{r}130 \\
\\
140 \\
150 \\
145 \\
\\
145 \\
145 \\
60\end{array}$ \\
\hline \multicolumn{3}{|c|}{ Safe limits (Axelsson) } & 80 & 80 & $50-500$ & $50-500$ & 80 & 80 & $50-500$ & $50-500$ \\
\hline
\end{tabular}

${ }^{1}$ Saws fitted with anti-vibration handles.

${ }^{2}$ Micrometres.

which is normally gripped by the left hand, and the lower handle, which incorporates the trigger-type throttle or accelerator and is normally gripped by the right hand.

The results from the two studies are, in general, similar. It would be expected that worn parts on the saws tested in Dundee would give rise to higher levels than were found in the new saws measured at NIAE. All measurements show levels considerably higher than the criterion of 80 microns (micrometres) amplitude in the range 50 to $500 \mathrm{~Hz}$, proposed by Axelsson (1968). The major component of the vibration is usually found in the $125 \mathrm{~Hz}$ octave band. The direction of this component varied on the upper handle but was vertical, i.e., normal to the direction of the chain bar, in 6 of the 7 saws tested in Dundee.

The use of anti-vibration mountings reduced the overall vibration level and lowered the frequency of the major component (see, in particular, saw C2).

\section{Estimation of prevalence of vibration syndrome}

Methods To estimate the prevalence of the vibration syndrome in forestry workers employed by the Forestry Commission, a survey was carried out on a sample of the employees covering England, Wales, and Scotland. A specially designed questionnaire was used, completed by the supervisor, in most cases the Forest District Officer. The questions concerning the vibration syndrome were included within a general health questionnaire, covering a number of health and safety aspects of forest work; this had the advantage that it avoided undue bias in the association between the syndrome and chain saws. Vibration syndrome was defined using the replies to the questions relating to blanching, numbness, and pain of the fingers, one or more 'yes' being taken as positive for the syndrome. Tremor of the hands was not accepted as positive when it occurred alone.

To ensure an adequate range of forest operations and adequate specialist work among employees in the sample, the survey was restricted to forests with more than 20 employees. Forty forests were chosen at random and 20 employees were selected from each, again by random sampling. The total sample was 800 out of 9600 . Of the employees selected, 44 had left the employment of the Commission, leaving 756 available for this study. To the first request, 679 persons $(90 \%)$ responded. By interviewing the sick on return to duty, by following movement within the Commission and by writing to first refusals requesting co-operation, an additional 53 replies were obtained, giving a total response of $732(97 \%)$. In this total were 21 females, leaving 711 males used for analysis.

\section{Results}

In the total sample of 711,142 men were chain saw operators and 569 were not. In the men using the chain saw the prevalence of the vibration syndrome was $44 \%$, while in men who did not handle the chain saw the prevalence was significantly lower at $18 \%$ (0.005 level of significance) (Table 2; Fig. 1). 
TABLE 2

Vibration Syndrome and Use of Chain SaW

\begin{tabular}{c|c|c|c}
\hline \multirow{2}{*}{$\begin{array}{c}\text { Vibration } \\
\text { syndrome }\end{array}$} & \multicolumn{2}{|c|}{ Use of chain saw } & \multirow{2}{*}{ Total } \\
\cline { 2 - 3 } & Yes & No & \\
\hline+ & $63(44 \%)$ & $102(18 \%)$ & $165(23 \%)$ \\
- & 79 & 467 & 546 \\
\hline Total & 142 & 569 & 711 \\
\hline
\end{tabular}

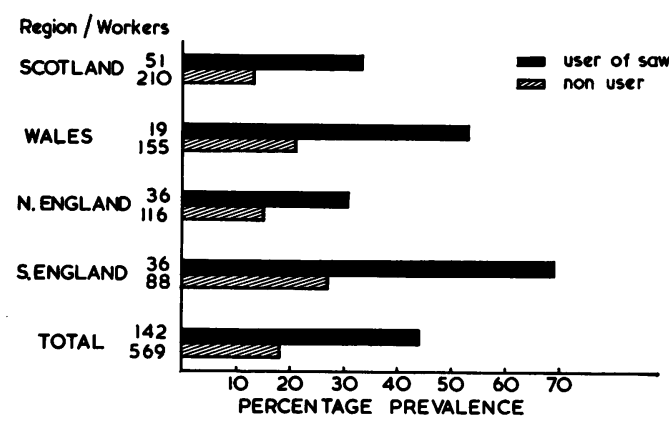

FIG. 1. Prevalence of vibration syndrome and use of chain saw in 711 forestry workers.

Among the chain saw users the prevalence was found to vary between the four regions studied. South England (south-west and south-east) showed the highest rate, $69 \%$, Wales had $53 \%$, and north England (north-west, north-east, and east conservancies) and Scotland had $31 \%$ and $33 \%$, respectively (Table 3; Fig. 1). These significant differences (0.005 level of significance) are in an unexpected direction, if climatic influences (e.g., low temperatures) are operating. In contrast, the small regional differences in prevalence seen among the men who did not use chain saws are not statistically significant $(P>0.05)$.

TABLE 3

Regional Differences in Prevalence of Vibration SyNDROME AND Use OF ChaIN SAW

\begin{tabular}{l|c|c|c|c}
\hline \multirow{2}{*}{ Region } & \multicolumn{2}{|c|}{ User } & \multicolumn{2}{c}{ Non-user } \\
\cline { 2 - 5 } & Syndrome & $\begin{array}{c}\text { No } \\
\text { syndrome }\end{array}$ & Syndrome & $\begin{array}{c}\text { No } \\
\text { syndrome }\end{array}$ \\
\hline Scotland & $17(33 \%)$ & 34 & $28(13 \%)$ & 182 \\
Wales & $10(53 \%)$ & 9 & $33(21 \%)$ & 122 \\
N. England & $11(31 \%)$ & 25 & $17(15 \%)$ & 99 \\
S. England & $25(69 \%)$ & 11 & $24(27 \%)$ & 64 \\
\hline Total & $63(44 \%)$ & 79 & $102(18 \%)$ & 467 \\
\hline
\end{tabular}

A further factor investigated was the number of years the men worked as chain saw operators. Prevalence rates were calculated for each year of saw use up to eight years, non-users being taken as zero years' use (Table 4; Fig. 2). A marked increase in prevalence is apparent over the eight years. In part, this effect explains the regional differences. It was not possible to calculate prevalence rates for different periods of saw usage in the regions, due to the small numbers involved. However, the average time spent as a chain saw user in the four regions shows marked differences in the same direction as the prevalence rates (Table 5).

It was thought that the method of travel to work could influence the occurrence of the syndrome by producing a pre-work reduction in temperature of the hands or body. The methods considered were

TABLE 4

Prevalence of Vibration Syndrome and Time Using ChaIn SaW

\begin{tabular}{c|r|r|r}
\hline \multirow{2}{*}{\begin{tabular}{c|c|} 
Time using \\
saw $(y r)$
\end{tabular}} & + & - & \multirow{2}{*}{ Total } \\
\cline { 2 - 3 } & \multicolumn{2}{|c|}{ Syndrome } & \\
\hline 0 & $102(18 \%)$ & 467 & 569 \\
1 & $10(31 \%)$ & 22 & 32 \\
2 & $9(30 \%)$ & 21 & 30 \\
3 & $7(37 \%)$ & 12 & 19 \\
4 & $6(40 \%)$ & 9 & 15 \\
5 & $10(63 \%)$ & 6 & 16 \\
6 and 7 & $5(63 \%)$ & 3 & 82 \\
$8+$ & $16(73 \%)$ & 6 & 711 \\
\hline Total & 165 & 546 & \\
\hline
\end{tabular}

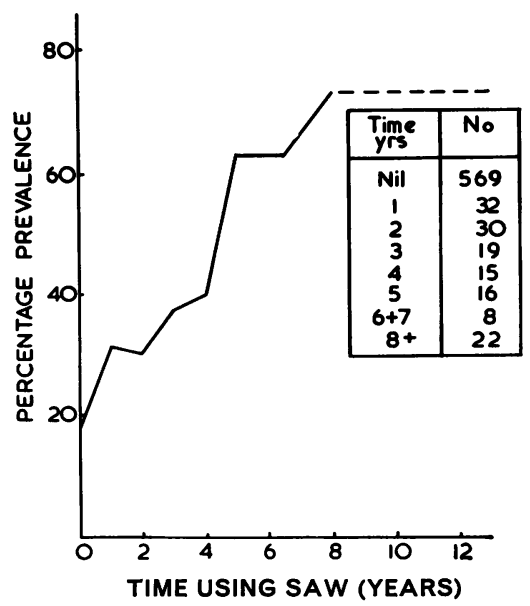

FIG. 2. Prevalence of vibration syndrome and time spent using chain saw in $\mathbf{7 1 1}$ forestry workers. 
TABLE 5

Average Time Using Chain Saw in the Four REgIONS STUdied

\begin{tabular}{l|c}
\multicolumn{1}{c|}{ Region } & $\begin{array}{c}\text { Mean time } \\
(y r)\end{array}$ \\
\hline Scotland & 3.67 \\
Wales & 7.42 \\
N. England & 3.58 \\
S. England & 6.72
\end{tabular}

walking and travelling by bicycle, motor cycle, bus, and car. The results are shown in Table 6. For all methods the saw users have higher rates than the controls. Among the users, those travelling by bicycle, motor cycle, and bus have higher rates than those travelling by other means. In the control group only motor cyclists show high rates. The rates are based on relatively small numbers and are not statistically significant.

The influence of climate was also investigated directly. Significantly more men with the syndrome were affected by chilling at work, during rest periods and whilst sheltering $(\mathrm{P}<0.005)$ (Table 7). Blanch-

TABLE 6

Prevalence of Vibration Syndrome and Method OF TRAVEL TO WORK

\begin{tabular}{l|r|r|r|r}
\hline \multirow{2}{*}{ Method $^{1}$} & \multicolumn{2}{|c|}{ User } & \multicolumn{2}{c}{ Non-user } \\
\cline { 2 - 5 } & Syndrome & $\begin{array}{c}\text { No } \\
\text { syndrome }\end{array}$ & Syndrome & $\begin{array}{c}\text { No } \\
\text { syndrome }\end{array}$ \\
\hline No travel. & $8(36 \%)$ & 14 & $2(5 \%)$ & 42 \\
Walking . & $10(42 \%)$ & 14 & $19(20 \%)$ & 77 \\
Bicycle . & $13(65 \%)$ & 7 & $10(14 \%)$ & 64 \\
Motor cycle & $4(57 \%)$ & 3 & $9(28 \%)$ & 23 \\
Bus $\quad .$. & $6(67 \%)$ & 3 & $6(13 \%)$ & 42 \\
Car $\quad$. & $23(43 \%)$ & 30 & $40(20 \%)$ & 159 \\
\hline
\end{tabular}

'Some men used more than one method.

TABLE 7

Chilling and Vibration Syndrome

\begin{tabular}{c|c|c}
\hline \multirow{2}{*}{ Questions } & \multicolumn{2}{|c}{ No. rep!ying 'yes' } \\
\cline { 2 - 3 } & $\begin{array}{c}\text { With } \\
\text { syndrome } \\
(165 \text { men })\end{array}$ & $\begin{array}{c}\text { Without } \\
\text { syndrome } \\
(546 \text { men })\end{array}$ \\
\hline $\begin{array}{l}\text { Do you get chilled at work? } \\
\text { Do you get chilled during } \\
\text { rest periods? }\end{array}$ & $52(32 \%)$ & $103(19 \%)$ \\
$\begin{array}{l}\text { Do you get chilled while } \\
\text { sheltering? }\end{array}$ & $95(58 \%)$ & $233(43 \%)$ \\
\hline
\end{tabular}

ing of the fingers $(89 \%)$ was most affected by the weather, followed by sensory loss $(84 \%)$, both of which become noticeably worse with cold or damp (Table 8).

TABLE 8

SyMPtOMS AFFECTED By WeATHER

\begin{tabular}{cc|c|c|c}
\hline Symptom & $\begin{array}{c}\text { No. with } \\
\text { symptoms }\end{array}$ & No. affected & Percentage \\
\hline Pain .. &.. & 53 & 31 & 58 \\
Numbness &. & 120 & 101 & 84 \\
Blanching &. & 83 & 74 & 89 \\
\hline
\end{tabular}

The final factor examined in this survey was smoking. The prevalence of the vibration syndrome was estimated in smokers, ex-smokers, and nonsmokers for both the chain saw users and the controls. The results are shown in Table 9 and Figure 3. Among the chain saw users a significant gradient is seen (smokers $52 \%$, ex-smokers $42 \%$, and nonsmokers $25 \%$ ) whereas in the controls the gradient is absent $(18 \%, 20 \%$, and $17 \%)$. This gradient cannot be explained by differences in time of exposure, smokers, ex-smokers, and non-smokers having spent approximately the same length of time using the saw.

TABLE 9

Prevalence of Vibration Syndrome and SMOKING HISTORY

\begin{tabular}{l|c|c|c|c}
\hline \multirow{2}{*}{$\begin{array}{c}\text { Smoking } \\
\text { history }\end{array}$} & \multicolumn{2}{|c|}{ Saw users } & \multicolumn{2}{c}{ Non-users } \\
\cline { 2 - 5 } & $\begin{array}{c}\text { With } \\
\text { syndrome }\end{array}$ & $\begin{array}{c}\text { Without } \\
\text { syndrome }\end{array}$ & $\begin{array}{c}\text { With } \\
\text { syndrome }\end{array}$ & $\begin{array}{c}\text { Without } \\
\text { syndrome }\end{array}$ \\
\hline Smoker . & $42(52 \%)$ & 39 & $62(18 \%)$ & 290 \\
Ex-smoker & $14(42 \%)$ & 19 & $24(20 \%)$ & 97 \\
Non-smoker & $7(25 \%)$ & 21 & $16(17 \%)$ & 80 \\
\hline
\end{tabular}

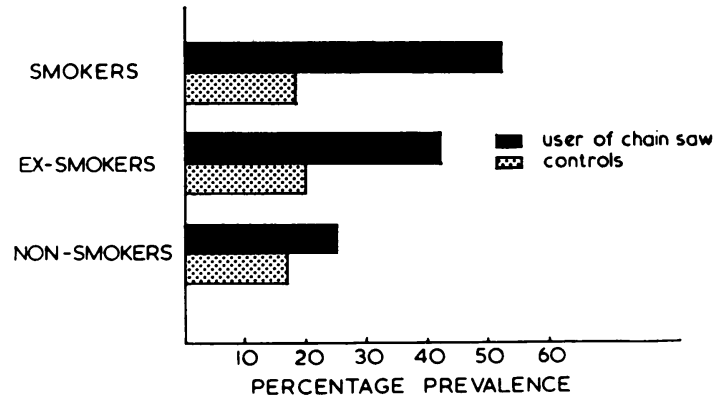

FIG. 3. Prevalence of vibration syndrome and smoking history. 


\section{Discussion and conclusions}

In this study the main interest centred on the role of chain saws in the production of the vibration syndrome in forestry work. The users of chain saws were compared with other Forestry Commission employees and they show a significantly higher rate of vibration syndrome. The prevalence in the "control' group is high $(18 \%)$. This 'control' group included employees exposed to vibration other than chain saws, e.g., pneumatic drill operators, tractor drivers, and drivers of tree-moving equipment. In addition, both groups will contain persons suffering from Raynaud's phenomenon of non-occupational origin and from constitutional cold fingers.

When reports of Raynaud's phenomenon of occupational origin are compared, the prevalences are markedly different. Figures vary from $25 \%$ (75 of 300 grinders; Telford, McCann, and MacCormack, 1945) through $48 \%$ (139 of 290 fellers; Kylin and his colleagues, 1968) to $93 \%$ (26 of 28 fettlers; Agate, Druett, and Tombleson, 1946). Examination of these results shows that the prevalence is related primarily to the length of exposure to vibration, and to a lesser extent to the physical characteristics of the vibration stimulus and the age of the operators. The regional differences found in this survey, when related to the average time spent as a chain saw user, support the view that a rising prevalence of the vibration syndrome is to be expected with increasing saw usage time (see Fig. 2). If this graph be extended it is likely that saw usage times of 10 to 12 years will result in a prevalence of white finger in the region of $90 \%$.

The survey indicated that a major factor precipitating attacks of white finger was a reduced environmental temperature once the condition was established. Attacks are more commonly found in winter (Hunter, McLaughlin, and Petty, 1945; Agate and his colleagues, 1946). The number of attacks is not related to the absolute temperature but to rapid falls in either the body or the hands. Hunt (1936) gave as examples of precipitating factors related to temperature, washing in cold water, picking up cold tools or utensils, and cycling to work on cold mornings. In Australia, Barnes and his colleagues (1969) quoted swimming, fishing, and watching football as leisure pursuits precipitating attacks. The evidence from this survey clearly showed that attacks commonly occur in the early morning, especially if chilling occurs early in the work day, and the number of attacks increases during rest periods in unheated shelters. As the prevalence of attacks rises with years of saw usage, the importance of the control of body temperature on travelling to work, or during rest periods, and whilst sheltering from inclement weather, becomes more important as a preventive measure.

Although this survey was mainly concerned with vibration white finger, the vibration characteristics of the tools, in this case chain saws, are reported for future reference. Previous work by Hunter and his colleagues (1945) had shown that there was a lower prevalence $(54 \%)$ among riveters working with guns vibrating at $35 \mathrm{~Hz}$ or below than among riveters working at between 35 and $50 \mathrm{~Hz}(74 \%)$ and fettlers working in the same 35 to $50 \mathrm{~Hz}$ range $(84 \%)$. It is essential, however, to know the amplitude range as well as the frequency in order to establish the traumatizing nature of the vibration. In forestry work there are wide variations in the physical stimulus received by the hand, evident by comparing the $86 \%$ prevalence in Tasmanian hardwood fellers with the $48 \%$ found in Swedish soft wood fellers (Grounds, 1964; Kylin and his colleagues, 1968). In the present study, the vibration characteristics of 18 chain saws are reported, seven of these actually taken from the forest before test and 11 new saws without any previous service life. All showed vibration amplitudes exceeding the safe limit of 80 microns (micrometres) (on either handle) advised by Axelsson. In some cases the measured amplitudes found exceeded the recommended safe limit of $\mathbf{8 0}$ microns (micrometres) by a factor of seven.

To reduce the rising prevalence of vibrationinduced white finger following the use of existing chain saws, immediate steps were taken by the Forestry Commission $(a)$ to encourage all saw manufacturers to develop anti-vibration mountings (a safe limit of 80 microns (micrometres) amplitude and below), (b) to replace all older saws of the nonAV type with the new designs for all regular operators before the end of October 1970, and (c) to ensure that all regular chain saw operators are using the recommended working techniques and are following the recommendations based on the research findings (see Appendix, p. 89). Whilst these preventive measures are being carried out in the field, a second study essentially clinical in approach will be made on a population of chain saw operators with a saw usage time of five years or more.

The authors gratefully acknowledge the financial assistance and encouragement given by the Forestry Commission. Our thanks are due to the Statistical Branch of the Commission, the Civil Service Department's Medical Adviser, and the staff and employees of the Commission's forests for their willing co-operation.

We are specially indebted to $\mathrm{Mr}$. John Matthews, Head of the Tractor and Ergonomics Department, National Institute of Agricultural Engineering, for the chain saw vibration analyses.

\section{References}

Agate, J. N. (1949). An outbreak of cases of Raynaud's phenomenon of occupational origin. Brit. J. industr. Med., 6, 144-163. 
- and Druett, H. A. (1947). A study of portable vibrating tools in relation to the clinical effects which they produce. Brit. J. industr. Med., 4, 141-163.

- - - and Tombleson, J. B. L. (1946). Raynaud's phenomenon in grinders of small metal castings. Brit. J. industr. Med., 3, 167.

Axelsson. Sven-Ake (1968). Analysis of Vibration in Power Saws. No. 59, Skogshogskolan. Royal College of Forestry Monograph, Stockholm.

Barnes, R., Longley, E. O., Smith, A. R. B., and Allen, J. G. (1969). Vibration disease. Med. J. Aust., 1, 901-905.

Dart, E. E. (1946). Effects of high speed vibrating tools on operators engaged in the airplane industry. Occup. Med., $1,515-550$.

Grounds, M. D. (1964). Raynaud's phenomenon in users of chain saws. Med. J. Aust., 1, 270-272.

Hamilton, A. (1918). A Study of Spastic Anaemia in the Hands of Stone Cutters. U.S. Department of Labor, Bureau of Labor Statistics, Bulletin 236 (Industrial Accidents and Hygiene Series, No. 19). Washington, D.C.

Hunt, J. H. (1936). Raynaud's phenomenon in workmen using vibrating instruments. Proc. roy. Soc. Med., 30, 171-178.

Hunter, D., McLaughlin, A. I., and Petty, K. M. A. (1945). Clinical effects of the use of pneumatic tools. Brit. J. industr. Med., 2, 10-16.

Kylin, B., Gerhardsson, G., Hansson, J., Litstrom, S., Ligenberg, B., Swensson, A., and Astrand, I. (1968). Halso-Och Miljoundersokning Bland Skogsarb Etare AI-Rapportz.

Loriga, G. (1911). Il labora coi martelli pneumatici. Boll. ispett, Lavoro 2, 35 and 6, 524 (1913).

Miura, T., Kimura, K., Tominaga, Y., and Kimotsuki, K. (1966). On the Raynaud's phenomenon of occupational origin due to vibrating tools - its incidence in Japan. Report of the Institute for Science of Labour, Tokyo, Japan, No. 65, 1-11.

Pecora, L. J., Udel, M., and Christman, R. P. (1960). Survey of current status of Raynaud's phenomenon of occupational origin. Amer. industr. Hyg. Ass. J., 21, 80-83.

Peters, F. M. (1946). A disease resulting from the use of pneumatic tools. Occup. Med., 2, 55-66.

Telford, E. D., McCann, M. B., and MacCormack, D. H. (1945). 'Dead hand' in users of vibrating tools. Lancet, 2, 359-360.

Vibration Syndrome (1970). Interim Report by the Industrial Injuries Advisory Council (Section 62 of National Insurance Industrial Injuries Act, 1965). Department of
Health and Social Security. Cmnd. 4430. H.M.S.O., London.

\section{Appendix}

Guidance given to chain saw operators by the Forestry Commission

There are a number of ways in which you can reduce the amount of vibration passing into your hands, when you are using any saw, and these points apply whether or not the saw has anti-vibration handles:

(1) Good techniques for felling, cross-cutting, and snedding with light-weight saws include resting the saw as much as possible on the tree (or occasionally on your thigh); this means that some of the vibration is absorbed by the tree or the large muscles of your thigh. Holding the saw as lightly as possible when it is at full throttle, without, of course, reducing effective control of the saw, will also reduce vibration absorbed into your hands.

(2) Wearing chain saw gloves spreads the grip over a larger area of your hands. (Often the first sign of white fingers is on one or two finger joints which have taken most of the vibration due to too tight a grip.)

(3) Good blood circulation to the arms and hands gives maximum protection to the flesh, nerves, and bones in the hands and this is achieved by warming up before starting the saw and wearing suitable clothing and gloves. Thus, it is better to be too warm than cold.

(4) Sprockets, guide bars, and chains should be well maintained, and chains should be correctly sharpened with the recommended clearance for the depth gauge. Poor maintenance increases vibration by as much as onethird of the normal level for the saw.

(5) The 'safe' limits are based on continuous use of the saw and every time the saw is idling or stopped gives your hands and arms a chance to recover from the effects of vibration. The more evenly breaks in saw usage can be spread throughout the day, the less the risk of any discomfort in your hands; try to organize the stops for fuel, sharpening, meals, piling of timber, or other work so that the saw is switched off for at least 10 minutes as often as possible during the day rather than a few longer stoppages.

Received for publication January 13, 1970. 